\title{
Osteological identification criteria for Capra pyrenaica and Capra hircus validated with DNA
}

\author{
$M^{a}$ Ángeles GALINDO-PELLICENA ${ }^{1 *}$, Irene UREÑA ${ }^{1}$, Cristina VALDIOSERA ${ }^{1,3}$ \& Juan \\ Luis ARSUAGA ${ }^{1,2}$
}

\author{
${ }^{1}$ Centro Mixto UCM-ISCIII de Evolución y Comportamiento Humanos. c/ Monforte de Lemos 5, pabellón 14. 28029 Madrid; \\ mariangape79@hotmail.com \\ ${ }^{2}$ Departamento de Paleontología. Facultad de Ciencias Geológicas. Universidad Complutense de Madrid. Ciudad Universitaria. \\ c/ José Antonio Novais 2. Madrid \\ ${ }^{3}$ Department of Archaeology and History. La Trobe University \\ * Corresponding author
}

Galindo-Pellicena, M.Á., Ureña, I., Valdiosera, C. \& Arsuaga, J.L. 2016. Osteological identification criteria for Capra pyrenaica and Capra hircus validated with DNA. [Validación por ADN de los criterios osteológicos diagnósticos para diferenciar Capra pyrenaica y Capra hircus]. Spanish Journal of Palaeontology, 31 (2), 297-304.

\section{ABSTRACT}

The taxonomic identification of Capra hircus and Capra pyrenaica from bone remains is essential in order to be able to infer a prehistoric society's subsistence strategy. Although osteometry is the criterion that is typically used to distinguish both of these species, Sarrión (1988) also defined morphological characteristics for distinguishing them. The objective of this work is to validate these morphological criteria with the genetic identification of ovicaprine bone remains from Palaeolithic and Neolithic levels of the Chaves site (Sierra de Guara, Huesca). The preliminary results indicate that the astragalus and calcaneus are more adequate for identifying Capra pyrenaica and Capra hircus and the discrimination criteria of mandibles and metacarpals are called into question.

Keywords: Capra pyrenaica, Capra hircus, DNA, Neolithic, Palaeolithic, Chaves site.

\section{RESUMEN}

La identificación taxonómica de Capra hircus y Capra pyrenaica a partir de sus restos óseos es esencial para inferir la estrategia de subsistencia de una sociedad prehistórica. Aunque el criterio de diferenciación entre ambas especies más utilizado es la osteometría, también se han definido caracteres morfológicos óseos que las diferencian (Sarrión, 1988). El objetivo de este trabajo es validar estos criterios morfológicos a partir de la identificación genética del material óseo de ovicápridos (ovejas y cabras: domésticas y salvajes) de los niveles paleolíticos y neolíticos del yacimiento de Chaves (sierra de Guara, Huesca). Los resultados preliminares indican que los astrágalos y calcáneos son los elementos anatómicos más adecuados para su identificación y se discuten los criterios de discriminación en las hemimandíbulas y metacarpos.

Palabras clave: Capra pyrenaica, Capra hircus, ADN, Neolítico, Paleolítico, yacimiento de Chaves. 


\section{INTRODUCTION}

The discrimination of Iberian ibex (Capra pyrenaica) and domestic goat (Capra hircus) (Artiodactila; Mammalia) (Wilson \& Reeder, 2005) is essential for inferring the subsistence strategy or economy of a population: hunter, livestock breeder or mixed economy. Therefore, an adequate taxonomic classification of goats at an archaeopalaeontological site is necessary in order to gain an understanding of prehistoric societies' way of life.

The differentiation between Iberian ibex (Capra pyrenaica) and domestic goat (Capra hircus) at a peninsular site is based on their difference in size: the Iberian ibex is bigger than the domestic goat. Nevertheless, the osteometric overlap among the big females and the small males must be considered (Altuna, 1978). On few occasions, the morphology of the bone remains, defined by Sarrión (1988), is used by zooarchaeologists for their differentiation.

Sarrión (1988) observed morphological differences in anatomical elements, such as mandibles, astragali, calcanei, metapodials (basically metacarpals) and phalanges. This study focuses on all of these anatomical elements.

The first objective is to carry out a detailed study of the diagnostic characteristics, which morphologically distinguish the bones of Iberian ibex and domestic goats from the Iberian Peninsula. The next objective is to validate the currently proposed morphological criteria, through genetic samples extracted from the bone remains of goats from Palaeolithic and Neolithic levels of the Chaves site. A complete morphological review, which distinguishes between wild and domestic goats, has been carried out. Some characteristics have been validated and some of them have been called into question.

\section{MATERIAL AND METHODS}

\subsection{Material}

The material is composed of 23 bone remains (five mandibles, 11 astragali, two calcanei, three metapodials and two phalanxes are included) of Iberian ibex and domestic goats from Palaeolithic and Neolithic levels of the Chaves site, according to zooarchaeological (osteometric and morphological methodology) criteria. Genetic information was recovered from 18 of the 23 bone remains using ancient DNA techniques. The results indicated that 18 bone remains belong to the genus Capra (Capra hircus or Capra pyrenaica). These 18 bone remains are the elements that have been used for the morphological analysis, because both genetics and zooarchaeological criteria that indicated that they belong to wild or domestic goats.
The Chaves cave is located in the Sierra de Guara (Huesca, Aragón). It comprises Upper Palaeolithic and Neolithic levels, clearly separated by a speleothem (Utrilla, 1992). The high frequency of wild goats, which were identified within Magdalenian (level IIa: 12,020 BP and level IIb: 12,800 BP), is noteworthy, and the site served as an area for hunting bucardos (Castaños, 1993). Bucardo is the Spanish common name of Capra pyrenaica pyrenaica: subspecies of Iberian wild goat from the Pyrenees which was recently extinct. In Neolithic levels, the Iberian goat constituted the most abundant wild ungulate followed by the deer (Castaños, 2004). The ovicaprines (Ovis aries and Capra hircus) are the best represented group from the Neolithic with 6,163 identified bone remains and a ratio (Ovis aries/Capra hircus) of 1.34 in level Ia and 1.76 in level Ib (Castaños, 2004).

\subsection{Zooarchaeological method}

In order to conduct palaeontological discrimination (Capra hircus versus Capra pyrenaica), metric data, considering the range of values between wild and domestic form, according to Altuna (1978) and morphological criteria following Sarrión (1988) were used.

In Neolithic levels, the presence of sheep (Ovis aries), in addition to goats (both Iberian ibex and domestic goat), has been considered. The osteometric (Payne, 1969) and morphological criteria for postcranial (Boessneck et al., 1964; Boessneck, 1969; Kratochvil, 1969; Prummel \& Frisch, 1986) and cranial elements (Payne, 1985; Helmer, 2000; Halstead et al., 2002) have been applied for their discrimination. A critical review is found in Zeder \& Pilaar (2010) and Zeder \& Lapham (2010).

\subsection{Genetic method}

All the DNA extractions were performed at the ancient DNA laboratory (Centro Mixto UCM-ISCIII, Madrid and EBC, Uppsala). Between 150 and $200 \mathrm{mg}$ of bone/tooth powder were used to conduct DNA extractions following a silica extraction method (Yang et al., 1998). For every 10 samples, 2 water negative controls were used. Each extract was eluted in a final volume of $60 \mu$ l Elution Buffer).

In order to identify the samples, a short fragment of the mitochondrial DNA was amplified. The primers Mbos L1269 and Mbos H1346 (Rollo et al., 2002) were used to amplify a $117 \mathrm{bp}$ fragment of the mitochondrial gene 12S).

The PCR amplification was conducted in $25 \mu 1$ using 1 X Smart-Taq Hot 10X PCR Buffer (Naxo), 1mM SmartTaq Hot 25mM MgCl2 solution (Naxo), $0.1 \mathrm{mM}$ dNTPs (Naxo), $0.2 \mu \mathrm{M}$ of each tagged primer (Biomers), one unit of Smart Taq Hot Polymerase 10U/ $\mu 1$ (Naxo) and $2 \mu \mathrm{l}$ of 
DNA extract. One PCR water control was prepared for every 10 samples. Thermal cycling conditions were $95^{\circ} \mathrm{C}$ for $15 \mathrm{~min}$ and $52 \mathrm{cycles}$ of $94^{\circ} \mathrm{C}$ for $30 \mathrm{sec}, 51-54^{\circ} \mathrm{C}$ for $30 \mathrm{sec}, 72^{\circ} \mathrm{C}$ for $30 \mathrm{sec}$, and $72^{\circ} \mathrm{C}$ for $10 \mathrm{~min}$. Amplicons were purified using ExoStarTM and sequenced at Centro Nacional de Investigaciones Oncológicas (the National Cancer Research Centre) or at Macrogen.

The results obtained were compared using BLAST with the available sequences in the GenBank for the different species of mammals.

\section{RESULTS}

DNA recovery and genetic identification were possible for 18 of the 23 samples: two of them were identified as Capra hircus, 16 as Capra pyrenaica.

The five mandibles were identified as belonging to Capra pyrenaica using osteometric (Table 1), as well as morphological and genetic criteria $(\mathrm{CH} 7, \mathrm{CH} 41, \mathrm{CH} 25$, CH27, and CH40) (Table 6).
The zooarchaeological identification (Table 2) of the metacarpal CH1 (Neolithic) suggested that it belonged to Capra pyrenaica; nevertheless, the genetic analysis indicated that this element belonged to Capra hircus (Table 6).

Nine out of the 11 astragali that were studied gave positive results from a DNA analysis. Eight of these nine were identified as Iberian ibex or domestic goat by zooarchaeological and genetic criteria: seven were identified as Capra pyrenaica (Tables 3, 6) (CH76, $\mathrm{CH} 77, \mathrm{CH} 80, \mathrm{CH} 82, \mathrm{CH} 83, \mathrm{CH} 10, \mathrm{CH} 20)$ and one as Capra hircus (CH98) (Table 6). The astragalus CH93 was identified as Ovis aries by osteometric and morphological criteria; nevertheless, the genetic criteria indicate that it belonged to Capra pyrenaica (Tables 3, 6).

The two analysed calcanei (CH18 from the Palaeolithic level and $\mathrm{CH} 8$ from the Neolithic) were identified as Capra pyrenaica, based on their large size (Table 4) and morphology. The genetic analysis indicated the same taxonomical identification (Table 6).

The second phalanx (CH6) was identified as Capra pyrenaica by zooarchaeological (Table 5 for osteometry) and genetic analysis (Table 6).

Table 1. Metric data of goat mandibles from Chaves. $\mathrm{LM}_{1}-\mathrm{M}_{3}$ : occlusal length $\mathrm{M}_{1}-\mathrm{M}_{3} ; \mathrm{LP}_{2}-\mathrm{P}_{4}$ : occlusal length $\mathrm{P}_{2}-\mathrm{P}_{4}$; $L M_{1}$ : length $\mathrm{M}_{1} ; \mathrm{LM}_{3}$ : length $\mathrm{M}_{3}$ (all values in $\mathrm{mm}$ ) Values [min-max, mean] of $\mathrm{LP}_{2}-\mathrm{P}_{4}$ for mandibles of Iberian ibex (Altuna, 1978): $[21-30,25.45]$.

\begin{tabular}{cccccccc} 
& & & $\mathrm{LM}_{1}-\mathrm{M}_{3}$ & $\mathrm{LP}_{2}-\mathrm{P}_{4}$ & $\mathrm{LM}_{3}$ & $\mathrm{BM}_{3}$ & $\begin{array}{c}\text { Osteometric } \\
\text { identification }\end{array}$ \\
\hline \multirow{5}{*}{ Mandibles } & $\mathrm{CH} 7$ & CH.90.8D.112.242 & 54.7 & 23.56 & 28.5 & 9.35 & Capra pyrenaica \\
\cline { 2 - 8 } & $\mathrm{CH} 25$ & CH.4G.292.54 & 50.7 & 22.48 & 22.94 & 10.43 & Capra pyrenaica \\
\cline { 2 - 8 } & $\mathrm{CH} 27$ & CH.5G.281.35 & 74.03 & 22.5 & 39.72 & 12.3 & Capra pyrenaica \\
\cline { 2 - 8 } & $\mathrm{CH} 40$ & CH.2G.290.88 & 72.31 & $\mathrm{X}$ & 31.43 & 10.1 & Capra pyrenaica \\
\cline { 2 - 8 } & $\mathrm{CH} 41$ & CH.2E.282.308 (9) & 51 & $\mathrm{X}$ & 20.5 & 5.3 & Capra pyrenaica \\
\hline
\end{tabular}

Table 2. Metric data of goat metacarpal from Chaves. Bd: distal width; WCM: medio-lateral width of the condyle; DEM: anteroposterior width of its external trochlea (all values in $\mathrm{mm}$ ). Values [min-max, mean] of $\mathrm{Bd}$ for metacarpal of Iberian ibex (Altuna, 1978): [31.5-41.5, 36.63] and for domestic goat: [23.5-28.4, 25.9] (Iborra, 2004).

\begin{tabular}{lcccccc} 
& & & Bd & WCM & DEM & Osteometric identification \\
\hline \multirow{4}{*}{ Metacarpal } & CH1 & CH.7C.1b.36 & 37.65 & 16.44 & 13.33 & Capra pyrenaica \\
\cline { 2 - 7 } & CH17 & CH2E.284.21 & 35.52 & 16.44 & 14.22 & Capra pyrenaica \\
\cline { 2 - 7 } & CH29 & CH.E2.285.33 & 36.63 & 17.49 & 15.91 & Capra pyrenaica \\
\hline
\end{tabular}

Therefore, 18 anatomical cranial and postcranial elements of Capra pyrenaica and Capra hircus have been analysed $(*$ in Table 6$)$ : nine astragali, one metacarpal, two calcanei, five mandibles and one second phalanx, which they were identified as either Iberian ibex or as domestic goats, by both zooarchaeological and genetic analysis.
Next, the morphological description of some samples is indicated.

On the left astragalus $\mathrm{CH} 10$ (Fig. 1). From plantar aspect, the junction between the proximo-plantar and lateral trochlea is rounded. The surface from medial to lateral side (c-d), if the astragalus were cut transversally, it 
Table 3. Metric data of goat astragalus from Chaves. GLl: greatest lateral length; GLm: greatest medial length; BL: lateral width; Bm: medial width; Bd: distal width (all values in $\mathrm{mm}$ ). Values [min-max] for GLl for astragalus [31.5-40.5, 36.68] and Bd [20-28. 23.88] of Iberian ibex (Altuna, 1978).

\begin{tabular}{|c|c|c|c|c|c|c|c|c|}
\hline & & & GLl & GLm & BL & $\mathrm{Bm}$ & $\mathrm{Bd}$ & $\begin{array}{c}\text { Osteometric } \\
\text { Identification }\end{array}$ \\
\hline \multirow{11}{*}{ Astragalus } & $\mathrm{CH} 10$ & CH.D.1b.103 & 40.73 & 36.54 & 22.3 & 22.57 & 24.36 & Capra pyrenaica \\
\hline & $\mathrm{CH} 20$ & CH.E2.280.11 & 39.34 & 36.72 & 21.9 & 22.43 & 26.38 & Capra pyrenaica \\
\hline & $\mathrm{CH} 76$ & CH.89A.1b.301 & 34.5 & 32.6 & 18.93 & 18.5 & 21.92 & Capra pyrenaica \\
\hline & $\mathrm{CH} 77$ & CH.92.14C.1a.199 & 38.08 & 36.62 & 20.97 & 21.75 & 23.76 & Capra pyrenaica \\
\hline & $\mathrm{CH} 78$ & No label & 38.7 & 34.88 & 20.97 & 20.88 & 25.29 & Capra pyrenaica \\
\hline & $\mathrm{CH} 80$ & No label & 34.38 & 32.06 & $\mathrm{X}$ & $\mathrm{X}$ & $\mathrm{X}$ & Capra pyrenaica \\
\hline & CH81 & No label & 34.95 & 32.43 & 18.59 & 18.72 & 21.85 & Capra pyrenaica \\
\hline & CH82 & No label & 33.74 & 31.6 & 18.58 & 18.01 & 21.92 & Capra pyrenaica \\
\hline & $\mathrm{CH} 83$ & No label & 34.03 & 32.61 & 18.47 & 18.85 & 22.84 & Capra pyrenaica \\
\hline & $\mathrm{CH}^{2} 3^{\mathrm{N}}$ & No label & 26.54 & 25.75 & 15.31 & 14.74 & 16.72 & Ovis aries \\
\hline & $\mathrm{CH}^{2} 8^{\mathrm{N}}$ & CH.92.12E.1a.71 & 28 & 25.8 & 16.6 & 17.01 & 17.5 & Capra hircus \\
\hline
\end{tabular}

Table 4. Metric data of goat calcaneus from Chaves. GL: greatest length; Bd: greatest width (all values in mm). Uf: unfused. Values [min-max, mean] of GL for calcaneus of Iberian ibex (Altuna, 1978): [65-86, 75.52] and for domestic goat (Iborra, 2004): [43.6-52, 47.8].

\begin{tabular}{cccccc} 
& & & GL & Bd & Osteometric identification \\
\hline \multirow{2}{*}{ Calcaneus } & CH8 & CH.6D.220.102 & uf 68.8 & 24.5 & Capra pyrenaica \\
\cline { 2 - 6 } & CH18 & CH.E4.280.270 & 70.97 & 24.33 & Capra pyrenaica \\
\hline
\end{tabular}

Table 5. Metric data of goat second phalanx from Chaves (all values in $\mathrm{mm}$ ).

\begin{tabular}{cccccccc} 
& & & GL & Bp & Bd & SD & Osteometric identification \\
\hline \multirow{2}{*}{ II phalanx } & CH6 & CH.92.10D.1b.92 & 28.4 & 16.2 & 12.36 & 12.32 & Capra pyrenaica \\
\cline { 2 - 8 } & CH15 & CH.E4.288.299 & 31.42 & 16.77 & 13.5 & 12.43 & Capra pyrenaica \\
\hline
\end{tabular}

would be slightly concave (a). Nevertheless, this surface is flat in domestic goats. The cavity (b) located among plantar and proximal trochlea (i.e., the contact point between it and the coracoid process of the calcaneus) is deep and sharpened. From a lateral aspect, the distal articular surface (e) is elongated and forms a kidney shape.

All morphological criteria (according to Sarrión, 1988) and genetic analysis indicate that this astragalus belongs to Capra pyrenaica.

These diagnostic criteria for Capra pyrenaica have been observed on six additional astragali $(\mathrm{CH} 20, \mathrm{CH} 76$, $\mathrm{CH} 77, \mathrm{CH} 80, \mathrm{CH} 82, \mathrm{CH} 83$ ), which are consistent with the taxonomic identification achieved through DNA analysis. The zooarchaeological and genetic criteria indicate that one of the astragalus (CH98) belongs to Capra hircus. Just one of the astragalus was identified as Ovis aries with zoorchaeological criteria, and the genetic results indicate that it belongs to Capra pyrenaica $(\mathrm{CH} 93$ in Table 6). Thus, seven of nine astragali (77.7\%) were

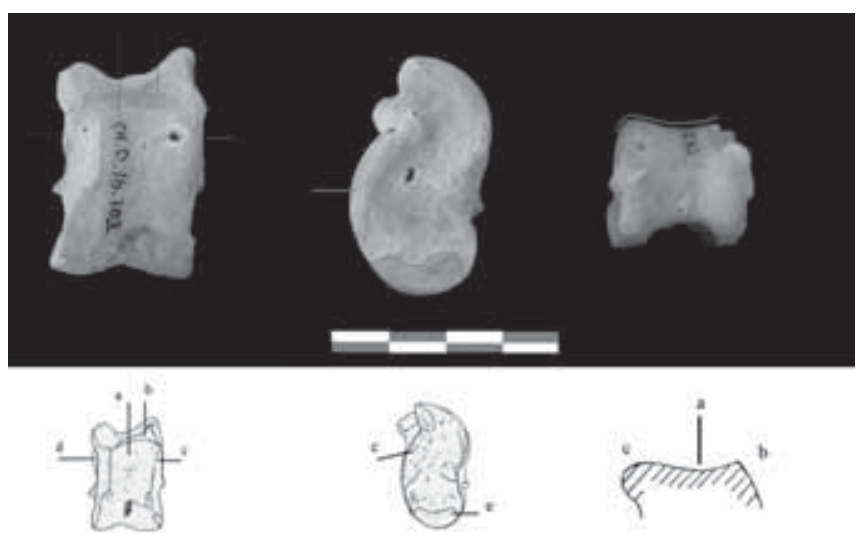

Figure 1. Picture of left astragalus (CH10) of Capra pyrenaica from Neolithic levels at the Chaves site. From left to right: plantar, lateral and proximal views. Scale: $4 \mathrm{~cm}$. Below: diagnostic criteria to distinguish astragalus of Capra pyrenaica and Capra hircus (taken from Sarrión, 1988). a, b, c, d, e: see description in the text. 
Table 6. Anatomical elements used for the study. AST: astragalus; MC: metacarpal; II FALN: II phalanx; MAN: mandible; CALC: calcaneus. O.a.: Ovis aries; C.h.: Capra hircus; C.py: Capra pyrenaica.

\begin{tabular}{|c|c|c|c|}
\hline & Anatomical element & Zooarchaeological criteria & DNA criteria \\
\hline $\mathrm{CH}^{2} 3^{\mathrm{N}}$ & AST & O.a. & C.py* \\
\hline $\mathrm{CH} 98^{\mathrm{N}}$ & AST & C.h. & C.h.* \\
\hline $\mathrm{CH}_{7} 6^{\mathrm{N}}$ & AST & C.py & C.py* \\
\hline $\mathrm{CH} 77^{\mathrm{N}}$ & AST & C.py & C.py* \\
\hline $\mathrm{CH} 78$ & AST & C.py & $\mathrm{X}$ \\
\hline $\mathrm{CH}^{2} 0^{\mathrm{N}}$ & AST & C.py & C.py* \\
\hline $\mathrm{CH} 81$ & AST & C.py & $\mathrm{X}$ \\
\hline $\mathrm{CH}_{8} 2^{\mathrm{N}}$ & AST & C.py & C.py* \\
\hline $\mathrm{CH}^{2} 3^{\mathrm{N}}$ & AST & C.py & C.py* \\
\hline $\mathrm{CH}^{\mathrm{N}}$ & $\mathrm{MC}$ & C.py & C.h.* \\
\hline $\mathrm{CH} 6^{\mathrm{N}}$ & II FALN & C.py & C.py* \\
\hline $\mathrm{CH} 7^{\mathrm{N}}$ & MAND & C.py & C.py* \\
\hline $\mathrm{CH} 8^{\mathrm{N}}$ & CALC & C.py & C.py* \\
\hline $\mathrm{CH} 10^{\mathrm{N}}$ & AST & C.py & C.py* \\
\hline $\mathrm{CH} 15^{\mathrm{P}}$ & II FALN & C.py & $\mathrm{X}$ \\
\hline $\mathrm{CH} 17^{\mathrm{P}}$ & $\mathrm{MC}$ & C.py & C.py* \\
\hline $\mathrm{CH} 18^{\mathrm{P}}$ & CALC & C.py & C.py* \\
\hline $\mathrm{CH} 20^{\mathrm{P}}$ & AST & C.py & C.py* \\
\hline $\mathrm{CH} 25^{\mathrm{P}}$ & MAND & C.py & C.py* \\
\hline $\mathrm{CH} 27^{\mathrm{P}}$ & MAND & C.py & C.py* \\
\hline $\mathrm{CH} 29^{\mathrm{P}}$ & MC & C.py & $\mathrm{X}$ \\
\hline $\mathrm{CH}_{40}{ }^{\mathrm{P}}$ & MAND & C.py & C.py* \\
\hline $\mathrm{CH}_{4} 1^{\mathrm{P}}$ & MAND & C.py & C.py* \\
\hline
\end{tabular}

identified as Capra pyrenaica through the use of diagnostic morphological and genetic criteria. Nevertheless, just one of the nine samples $(11.11 \%)$ that belongs to Capra hircus as identified using morphological criteria (Zeder \& Lapham, 2010), was identified as Capra hircus through genetic criteria. One of the nine astragali was identified as Ovis aries by morphological criteria and as Capra pyrenaica with DNA identification.

In the case of the calcaneus $\mathrm{CH} 8$ (Fig. 2), the junction between the coracoid process and the articular facet for the os malleolare is rounded (a) (the negative of the astragalus morphology) and the side of the coracoid is curved (c). On the cavity's articular surface for the trochlea of the astragalus, the surface is joined in proximal parts (b). Both morphological and genetic criteria indicate the calcaneus CH8 belongs to Capra pyrenaica.

The calcaneus $\mathrm{CH} 18$ presents diagnostic morphological characteristics of Capra pyrenaica so that, through the use of palaeontological criteria like genetics, it concurs with the taxonomic identification.

The mandible $\mathrm{CH} 7$ (Fig. 3) includes the almost complete cheektooth row $\left(\mathrm{P}_{3}-\mathrm{M}_{3}\right)$, missing $\mathrm{P}_{2}$. The lack of a second premolar is a characteristic that is typical of the Capra pyrenaica mandible, according to Sarrión (1988). This missing second premolar is due to lack of entity in the roots, which causes its loss from the alveoli (Sarrión, 1988). The index that indicates this characteristic has been calculated:

$$
\operatorname{Index}(\mathrm{CH} 7)=\left(\mathrm{LP}_{2} * 100\right) / \mathrm{LP}_{3}=(3.5 * 100) / 5.5=63.63
$$

where LP: alveolar length of premolar; P2: second premolar; P3: third premolar.

This result is closer to the average value from the Capra hircus index than to the Capra pyrenaica index average value, according to Sarrión (1988).

The mandibles $\mathrm{CH} 40$ and $\mathrm{CH} 41$ have no $\mathrm{P}_{2}$, and the alveoli are reabsorbed, so the metric data of the alveoli length have not been taken and the index could not be calculated. The genetic analysis indicates that these mandibles belong to Capra pyrenaica.

The $\mathrm{P}_{2}$ is missing in mandible $\mathrm{CH} 25$, which is a typical characteristic of Capra pyrenaica, and the index $=(2.8 * 100) / 4.5=62.22$ indicates a value closer to Capra 

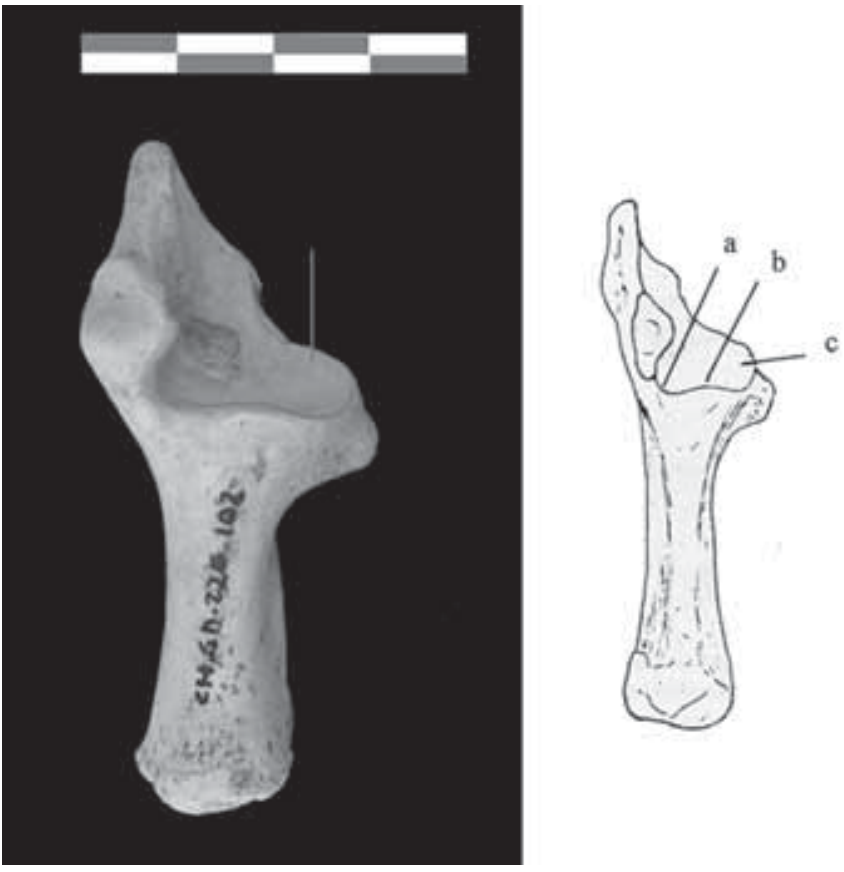

Figure 2. Left: calcaneus (CH8) of Capra pyrenaica from the Neolithic levels of Chaves, in dorsal view. Scale: 4 $\mathrm{cm}$. Right: diagnostic morphological criteria of Capra pyrenaica, according to Sarrión (1988). a, b, c: see description in the text.

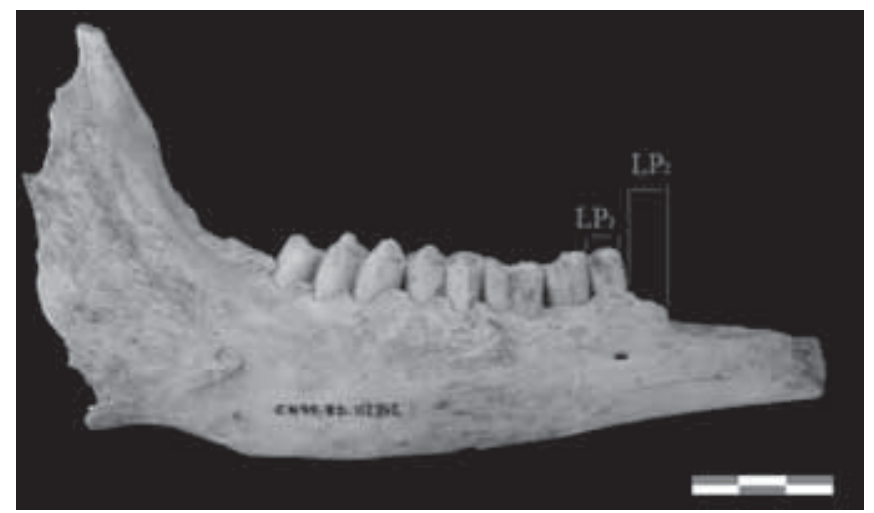

Figure 3. Picture of right mandible $(\mathrm{CH} 7)$ of Capra pyrenaica from Neolithic levels of the Chaves site. Scale: 3 $\mathrm{cm}$. LP2: length of second premolar; LP3: length of third premolar.

hircus than the index of Capra pyrenaica. The genetic analysis indicates that this mandible belongs to Capra pyrenaica.

The $\mathrm{P}_{2}$ is missing in the mandible $\mathrm{CH} 27$ and the index $=(3.9 * 100) / 6=65$ indicates that the value is closer to Capra hircus than the index of Capra pyrenaica. The genetic analysis indicates that this mandible belongs to Capra pyrenaica.

The size of the mandibles and the chronology of the level (Palaeolithic) indicate that the five mandibles belong to $C$. pyrenaica. The missing $\mathrm{P}_{2}$ is observed in all mandibles. The index could be calculated in three of the five mandibles. The three mandibles have an index closer to C. hircus than C. pyrenaica. The DNA analysis conducted on the mandibles indicates that they belonged to Capra pyrenaica.

The morphological criteria of the metacarpal CH1 (Fig. 4) have been described in order to check the taxonomic identification. In dorsal aspect, the distal third of the diaphysis is flat (b) without epiphysis protuberances and links to distal articular surface without (or with slight) cavities above (a). The cavities, located above the distal articular surfaces, are slightly marked, opposite of the Capra hircus metacarpal, which has very marked cavities. In lateral or medial aspect, if a line was extended from the anterior surface of the diaphysis to the distal articular surface, the line should cut the distal articular surface (c). All morphological characteristics indicate that this metacarpal belongs to Capra pyrenaica according to Sarrión (1988). However, the DNA analysis showed haplotypes of Capra hircus.

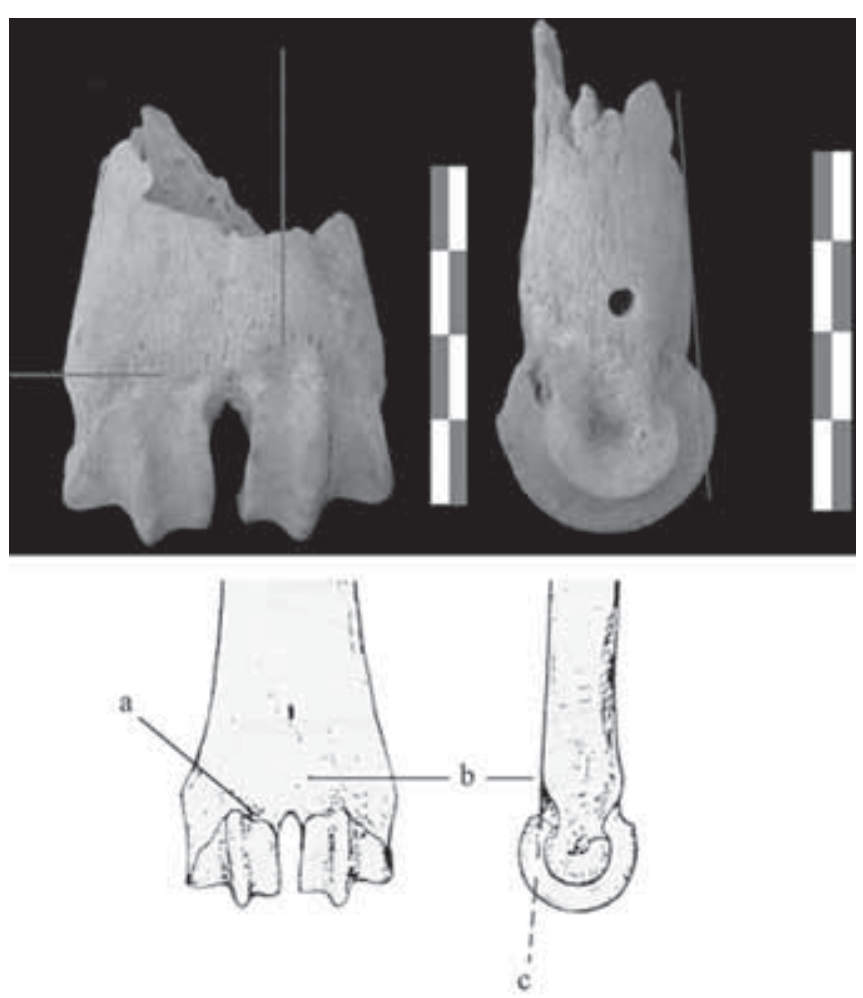

Figure 4. Metacarpal (CH1) of Capra pyrenaica from the Neolithic levels of the Chaves site. From left to right: dorsal view and lateral view. Scale: $4 \mathrm{~cm}$. a, b: See description in the text.

The morphological and genetic criteria are in agreement with regard to the second phalanx (CH6) in that it belongs to Capra pyrenaica. 


\section{DISCUSSION}

The morphological and genetic criteria gave the same taxonomical identification of goat (wild or domestic) in $91.67 \%$ (11 of 12 anatomical elements) of the analysed samples of astragalus, calcaneus and second phalanx. Therefore, these anatomical elements are considered appropriate for their identification.

A missing $\mathrm{P}_{2}$ is observed in $100 \%$ of the analysed mandibles and thus, we consider it to be a valid criterion for taxonomic identification of Capra pyrenaica (Table 7). Nevertheless, the calculation of the dental index does not match the expected rate in any of the analysed mandibles. Therefore, this criterion is not valid for distinguishing $C$. hircus and C. pyrenaica.

Table 7. Summary of the zooarchaeological and DNA results for the identification of goats using the mandibles from the Chaves site.

\begin{tabular}{cccccc} 
Mandibles & $\begin{array}{c}\text { Missing } \\
\mathrm{P}_{2}\end{array}$ & Index & Size & Chronology & $\begin{array}{c}\text { DNA } \\
\text { analysis }\end{array}$ \\
\hline $\mathrm{CH} 7$ & Yes & $\begin{array}{c}63.63 \\
\text { C.hi }\end{array}$ & C.py & $\begin{array}{c}\text { Palaeolithic } \\
\text { (C.py) }\end{array}$ & C.py \\
\hline $\mathrm{CH} 25$ & Yes & $\begin{array}{c}62.22 \\
\text { C.hi }\end{array}$ & C.py & $\begin{array}{c}\text { Palaeolithic } \\
\text { (C.py) }\end{array}$ & C.py \\
\hline CH27 & Yes & 65 C.hi & C.py & $\begin{array}{c}\text { Palaeolithic } \\
\text { (C.py) }\end{array}$ & C.py \\
\hline CH40 & Yes & X & C.py & $\begin{array}{c}\text { Palaeolithic } \\
\text { (C.py) }\end{array}$ & C.py \\
\hline CH41 & Yes & X & C.py & $\begin{array}{c}\text { Palaeolithic } \\
\text { (C.py) }\end{array}$ & C.py \\
\hline
\end{tabular}

In the case of the metacarpal, the criteria according to Sarrión (1988) for identifying C. pyrenaica does not concur with genetic results, so these must be used with caution.

\section{CONCLUSIONS}

The morphological criteria of the anatomical elements described by Sarrión (1988) for distinguishing between Capra pyrenaica and Capra hircus have been assessed using DNA analysis. The zooarchaeological analysis is consistent with the genetic analysis on astragalus, calcaneus and second phalanges from Palaeolithic and Neolithic levels at the Chaves site. Some morphological criteria of mandibles and metacarpals are not consistent with the genetic analysis for their identification, so these criteria must be used with caution.

Despite the fact that this analysis is preliminary and more samples are necessary in order to assess the morphological criteria, the criteria considered a valid link to osteometry are sufficient to identify Capra pyrenaica without DNA analysis.

\section{ACKNOWLEDGEMENTS}

This research has been supported by financial assistance of the Spanish Society of Palaeontology. M.A. GalindoPellicena is also being supported by postdoctoral grant from the Fundación Atapuerca. The financial support for the Atapuerca project has been provided by the research projects MICICINN CGL2012-38434-C03-01 and MINECO/FEDER CGL2015-65387-C3-2-P. We are grateful to Museum of Huesca, in special mention to Prof. Pilar Utrilla for allowing us the study of Palaeolithic bones remains and to Vicente Baldellou (in memoriam) for allowing us the study of Neolithic bones remains. Also we are grateful to Wietske Prummel and another anonymous reviewer for their comments that have improved the previous version of the manuscript.

\section{REFERENCES}

Altuna, J. 1978. Dimorphisme sexuel dans le squelette postcephalique de Capra pyrenaica pendant le Würm Final. Munibe, 4, 201-214.

Boessneck, J. 1969. Osteological differences between sheep (Ovis aries Linné) and goats (Capra hircus Linné). In: Science in Archaeology (eds Brothwell, D. \& Higgs, E.). London, 331-358.

Boessneck, J., Müller, H.H. \& Teichert, M. 1964. Osteologische Unterscheidungsmerkmalezwischen Schaf (Ovis aries Linné) und Ziege (Capra hircus Linné). Kühn-Archiv, $78,1-129$.

Castaños, P.M. 1993. Estudio de los macromamíferos de los niveles paleolíticos de Chaves (Huesca). Bolskan: revista de arqueología del Instituto de Estudios Altoaragoneses, 10, 9-30.

Castaños, P.M. 2004. Estudio zooarqueológico de los macromamíferos del Neolítico de la Cueva de Chaves. Saldvie, 4, 125-71.

Halstead, P., Collins, P. \& Isaakidou, V. 2002. Sorting the sheep from thegoats: Morphological distinction between the mandibles and mandibular teeth of adult Ovis and Capra. Journal of Archaeological Science, 29, 545-553.

Helmer, D. 2000. Discrimination des genres Ovis et Capra à l'aide desprémolaires inférieures 3 et 4 . L'exemple de Dikili Tash (Macédoine-Grèce). Ibex, Journal of Mountain Ecology / Anthropozoologica, 5/31, 29-38.

Iborra, I. 2004. La ganadería y la caza desde el Bronce Final hasta el Ibérico Final en el territorio valenciano, 103. Servicio de Investigación Prehistórica. Serie de Trabajos Varios. Valencia. 
Payne, S. 1969. A metrical distinction between sheep and goat metacarpals. In: The Domestication and Exploitation of Plants and Animals (eds Ucko, P.J. \& Dimbleby, G.W.). Duckworth, London, 295-305.

Payne, S. 1985. Morphological distinction between the mandibular teeth of young sheep, Ovis, and goats, Capra. Journal of Archaeological Science, 12, 139-147.

Kratochvil, Z. 1969. Species criteria on the distal section of the tibia in Ovis ammon $f$. aries L. and Capra aegragus f. hircus L. Acta veterinaria Brno, 38, 483-490.

Prummel, W. \& Frisch, H.-J. 1986. A guide for the distinction of species, sex and body size in bones of sheep and goat. Journal of Archaeological Science, 13, 567-577.

Rollo, F., Ubaldi, M., Ermini, L. \& Marota, I. 2002. Ötzi's last meals: DNA analysis of the intestinal content of the Neolithic glacier mummy from the Alps. Proceedings of the National Academy of Sciences of the United States of America, 99, 20, 12594-12599; doi: 10.1073/ pnas. 192184599.

Sarrión, I. 1988. Notas sobre una morfología diferenciada en los restos óseos de Capra Pyrenaica y Capra hircus. Archivo de Prehistoria Levantina, XVIII, 129-134.
Utrilla, P. 1992. Aragón/Litoral mediterráneo. Relaciones durante el Paleolítico. Actas del Congreso Aragón/Litoral Mediterráneo, 9-35. Zaragoza.

Yang, D.Y., Eng, B., Waye, J.S., Dudar, C.J. \& Saunders, S.R. 1998. Technical note: Improved DNA extraction from ancient bones using silica-based spin columns. American Journal of Physical Anthropology, 105, 539-543; doi: 10.1002/(SICI)1096-8644(199804)105:4<539::AIDAJPA10>3.0.CO;2-1.

Wilson, D.E. \& Reeder, D.M. (eds) 2005. Mammal Species of the World, a Taxonomic and Geographic Reference. Third edition, Smithsonian Institution Press, Washington, D.C.

Zeder, M.A. \& Lapham, H.A. 2010. Assessing the reliability of criteria used to identify postcranial bones in sheep, Ovis, and goats, Capra. Journal of Archaeological Science 37, 2887-2905; doi: 10.1016/j.jas.2010.06.032.

Zeder, M.A. \& Pilaar, S.E. 2010. Assessing the reliability of criteria used to identify mandibles and mandibular teeth in sheep, Ovis, and goats, Capra. Journal of Archaeological Science 37, 225-242; doi: 10.1016/j.jas.2009.10.002. 